\title{
AN EMPIRICAL L2 PERSPECTIVE ON POSSESSIVES: FRENCH/NORWEGIAN
}

\author{
HANS PETTER HELLAND \\ University of Oslo
}

\section{A BSTRACT}

The main objective of this paper is to present empirical evidence for transfer effects between Norwegian (as L1 or L2) and French (as L1 or L2). We start out with theoretical assumptions from a contrastive-comparative treatment of possessives in European languages (Fabricius-Hansen et al. 2017) and develop hypotheses for L2-acquisition of possessive systems in Norwegian and French. The various degrees of complexity between the two linguistic sub-systems lead to different kinds of challenges in L2-acquisition based on morphological, syntactic and semantic criteria. Norwegian has a morphologically more complex possessive system than French. The French learner of Norwegian as L2 then has to acquire a system with more formal options than in her mother tongue, whereas the Norwegian learner of French as L2 acquires a system with less formal options. Based on empirical findings, the paper shows why some parts of the possessive L2 systems are harder or easier to handle than others.

\section{[1] INTRODUCTION}

In this chapter, we discuss empirical questions related to the acquisition of the possessive systems in French as L2 (Fr2) and Norwegian as L2 (No2). Based on the theoretical background of Fabricius-Hansen et al. (2017) we will see how the diverging possessive systems of the two languages in question represent challenges for production as well as comprehension. The main objective of this chapter is to present empirical evidence for transfer effects between the learners' L1 and the L2.

In section [2] we recall some of the main points concerning the contrasts between the French and Norwegian system. We develop in section [3] some hypotheses for the language pair Norwegian-French which are tested against data from our empirical investigation. As will be clear, the tests can be elaborated and refined for future research. 
[2] NORWEGIAN AND FRENCH POSSESSIVES IN CONTRAST

Norwegian has two sets of possessive determiners marking morphologically the reflexive-irreflexive distinction in the third person: ${ }^{1}$

(1) $\operatorname{Han}_{\mathrm{i}}$ fant igjen bilen $\sin _{\mathrm{i}} / \sin _{\mathrm{i}} \quad$ bil.

he found again car.DEF POSS.REFL/POSS.REFL car

(2) $\mathrm{De}_{\mathrm{i}}$ fant igjen bilen $\sin _{\mathrm{i}} / \sin _{\mathrm{i}}$ bil.

they found again car.DEF POSS.REFL/POSS.REFL car

(3) ${ }^{*} \mathrm{Han}_{\mathrm{i}}$ fant igjen bilen hans ${ }_{\mathrm{i}} /$ hans $_{\mathrm{i}}$ bil.

he found again car.DEF his.IRREFL/his.IRREFL car

(4) ${ }^{*} \mathrm{De}_{\mathrm{i}}$ fant igjen bilen deres $\mathrm{i}_{\mathrm{i}} /$ deres $_{\mathrm{i}}$ bil.

they found again car.DEF their.IRREFL/their.IRREFL car

The reflexive possessives in (1) and (2) (through coindexation and principle A of Binding Theory) are bound by the pronominal subjects meaning unambiguously that he and they necessarily got their own cars back. In contrast, the irreflexive possessives in (3) and (4) exclude binding from the subjects, meaning that the pronominal subjects (he and they) found someone else's car, not their own. In such cases, reflexive and non-reflexive possessives are in complementary distribution. ${ }^{2}$ When comparing the Norwegian examples in (1)-(2) and (3)-(4) with their French counterparts in (5)-(6), we see that the obligatorily preposed French possessives son and leur accept binding both clause-internally - from the local subjects (il and ils) - and clause-externally. The French third person possessives however vary in number with respect to the possessor, yielding third person singular son or plural leur:

(5) $\quad \mathrm{Il}_{\mathrm{i}}$ a retrouvé $\mathrm{sa}_{\mathrm{i} / \mathrm{j}}$ voiture/*voiture sa.

he found again poss car

(6) Ils $s_{\mathrm{i}}$ ont retrouvé leur $\mathrm{r}_{\mathrm{j} / \mathrm{j}}$ voiture/*voiture leur. they found again poss car

Concerning the reflexivity parameter the French possessive determiners in (5) and (6) are thus potentially ambiguous, letting the context decide if they are to be interpreted as reflexives or non-reflexives. Tables 1 and 2 summarize the properties

[1] The Norwegian possessive may occur in postnominal or prenominal position. In the former case the head noun must be doubly specified for definiteness, through a definite suffix (bil-en) and the postposed possessive determiner (see Fabricius-Hansen et al. (2017), section 3.3).

[2] It should be mentioned that examples like the starred (4) with plural possessor and reflexive meaning of the non-reflexive form (deres) are in fact easily attested for Norwegian. They are still considered ungrammatical for normative reasons ( ${ }^{*} D e_{\mathrm{i}}$ fant igjen bilen deres $\mathrm{s}_{\mathrm{i}} /$ deres $_{\mathrm{i}}$ bil), cf. Fabricius-Hansen et al. (2017), section 3.1. 


\begin{tabular}{lll}
\hline $\begin{array}{l}\text { Inherent properties of ante- } \\
\text { cedent (possessor) DP/referent }\end{array}$ & Possessive & Reflexivity (Binding condition) \\
\hline $\begin{array}{lll}\text { Sg. Masc./Fem. } \\
\text { Plural }\end{array}$ & $s^{* a}$ & Neutral ( \pm local binding) \\
\hline
\end{tabular}

[a] The starred short forms, $s^{*}$, leur* etc. mean that these are variants of fully inflected forms: son/sa/ses leur/leurs etc.

TABLE 1: French third person possessives.

\begin{tabular}{lll}
\hline $\begin{array}{l}\text { Inherent properties of ante- } \\
\text { cedent (possessor) DP/referent }\end{array}$ & Possessive & Reflexivity (Binding condition) \\
\hline No restrictions & si $^{*}$ & Reflexive (local binding) \\
Sg. masc. human & hans & Irreflexive (non-local binding) \\
Sg. fem. human & hennes & \\
Sg. comm. nonhuman & dens & \\
Sg. neut. (nonhuman) & dets & \\
Plural & deres & \\
\hline
\end{tabular}

TABLE 2: Norwegian third person possessives.

of the French possessive system in the third person compared to Norwegian.

French is similar to German in not distinguishing between reflexive and irreflexive possessives (Fabricius-Hansen et al. (2017) and Pitz et al. (2017)). Moreover, neither German nor French makes the human/nonhuman possessor distinction. But contrary to German, French does not mark the gender of the possessor whether in the singular or the plural. In other words, son $N$ may apply to a third person singular human possessor - either masculine (son $\mathrm{N}$ à lui) or feminine (son $\mathrm{N}$ à elle) - and even to a third person singular nonhuman possessor. Once the (human or nonhuman) $s^{*}$-possessor stem is determined, the agreement features on the noun are given by the possessum noun alone: son/sa/ses $N$.

The French learner of No2 has to deal with a morphologically (far) more complex system in the target language than in her mother tongue, and the morphological similarities between the systems, French $s^{*}$ and Norwegian $s i^{*}$ - turning out to be false friends - even open up for wrong transfer predictions; see FabriciusHansen et al. (2017, section 4). What is an explicit marking in Norwegian both for the reflexive-irreflexive and for the thuman possessor distinction (between $s i^{*}$ and hans/hennes/dens/dets/deres) is subsumed under one single form in the third person singular in French. Yet, without making the reflexive and irreflexive distinction, French has separate forms for third person singular and plural possessors. 

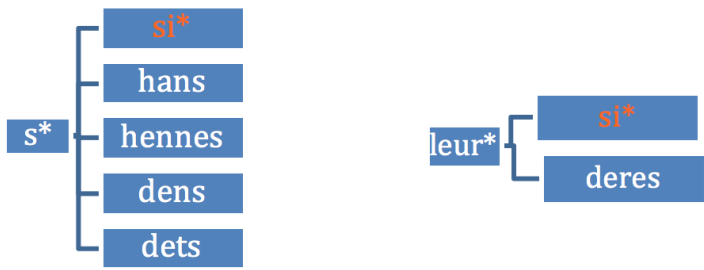

FIGURE 1: French-Norwegian divergence-convergence.

Conversely, Norwegian learners of Fr2 acquire a system on the one hand with less morphological options (no reflexive-irreflexive marking, no gender marking of the possessor, no \pm human marking of the possessor), but on the other hand with additional marking of the number feature ( $s^{*}$ vs. leur*) of the possessor which in Norwegian is marked only in the non-reflexive paradigm.

The differing points between the French and Norwegian systems may be summed up in a simplified fashion as in figure 1.

Our main objective in the following is to determine how such systemic differences influence the processes of acquiring Norwegian or French as L2 by French and Norwegian speaking learners respectively. In the next sections, we formulate some specific hypotheses both relating to the command of No2 possession by French learners and Fr2 possession by Norwegian learners and test them against data.

[3] HYPOTHESES AND EMPIRICAL TESTS

[3.1] Norwegian as L2: testing French learners' command of No2 possessives We predicted in Fabricius-Hansen et al. (2017) that French No2-learners have problems choosing between possessive $s i^{*}$ and its irreflexive counterparts hans/hennes/ dens/dets/deres. One could therefore formulate a hypothesis like the following:

H1 French No2+ learners of Norwegian make errors involving si* versus hans/ hennes/dens/dets/deres.

Let's see how this hypothesis can be tested. In the first place we will distinguish between grammaticality judgment tests and translation tests focusing both on relevant linguistic knowledge (judgment tests) and on production and comprehension tasks (translation tests).

\section{Judgment test}

We find evidence for $\mathrm{H} 1$ in a (monolingual) grammaticality judgment task performed on 14 French learners of Norwegian, all aged between 16 and 18 with two to three years of Norwegian training in school (three hours per week). The tests 
took place at Lycée Alain Chartier in Bayeux during the spring and autumn of 2016 where Norwegian is taught as an optional subject based on the Norwegian upper secondary school system. ${ }^{3}$ The judgment test contained twelve Norwegian test sentences with determiners including possessives followed by five contextually isolated sentences for translation French-Norwegian and took the following form (see appendix for the full test): ${ }^{4}$

\section{Test 1: No2 grammaticality judgment test}

Le possessif en norvégien

Test de jugement grammatical ${ }^{a}$

Déterminez si les possessifs soulignés dans les phrases suivantes sont acceptables ou non.

Akseptabel = acceptable/ikke akseptabel = non acceptable/vet $i k k e=$ je ne sais pas.

(i) Kristoffer har tre brødre, men han har ikke sett den yngste av brødrene hans det siste året.

hans = akseptabel/ikke akseptabel/vet ikke

(ii) Jeanette rydder sjelden rommet sitt.

sitt $=$ akseptabel/ikke akseptabel/vet ikke

(iii) Christian har en søster. Søsteren sin er lærer.

$\sin =$ akseptabel/ikke akseptabel/vet ikke

(iv) Foreldrene solgte huset sitt da de flyttet til Frankrike.

sitt $=$ akseptabel/ikke akseptabel/vet ikke

[a] 'Grammaticality judgment test. Decide if the underlined possessives in the following sentences are acceptable or not: acceptable/non-acceptable/don't know.'

[3] The upper secondary school in the Norwegian system has three levels: VG1, 2 and 3. In our data set we have nine informants from Bayeux from the spring of 2016 - of which seven are from VG2 and two from VG3. We still only count 14 informants from Bayeux in our samples below. The reason is that seven of the first nine informants took the same test six months later. The total number of informants are therefore 14.

[4] To date, no large scale experiments have been conducted on the acquisition of either Fr2 by Norwegian learners or No2 by French learners (but see Woldsnes (2013) for comparisons between the two systems for inalienables). What we refer to below must therefore be seen as preliminary tests. These tests have been designed by Anne-Kathrine Woldsnes and Hans Petter Helland (both from the University of Oslo) with input from the SPROSS-group, http://www.hf.uio.no/ilos/english/research/projects/ language-as-product-and-process/, cf. Fabricius-Hansen et al. (2017). 
Test 1 includes clear-cut grammatical as well as ungrammatical sentences, for instance (7)-(8): ${ }^{5}$

(7) Jeanette $\mathrm{i}_{\mathrm{i}}$ rydder sjeldent rommet $\sqrt{ }$ sitt $_{\mathrm{i}}$.

Lit.: 'Jeanette seldom cleans her.REFL room.'

(8) Kristoffer ${ }_{i}$ har tre brødre, men han ${ }_{i}$ har ikke sett den yngste av brødrene *hans $\mathrm{i}_{\mathrm{i}}\left(\mathrm{V}_{\mathrm{sine}} \mathrm{i}_{\mathrm{i}}\right)$ det siste året.

Lit: 'Kristoffer has three brothers, but he has not seen the youngest of *his.IRREFL (Vhis.REFL) brothers the last year.'

The main focus of the test is on third person possessives, both singular and plural, and mainly based on the reflexive-irreflexive distinction. The judgments of the informants will then give us an indication of how well the reflexive-irreflexive distinction is integrated in the grammar of the French No2 learner

Let's have a look at some examples. Since the possessive in (8) refers back to the subject referent of the same clause, the only grammatically correct form is the reflexive sin. The example in (8) is therefore clearly ungrammatical. However, five of fourteen French No2 students found the sentence acceptable, two were uncertain and only $7 / 14$ judged it (correctly as) ungrammatical. The same pattern is repeated for the ungrammatical (9), which demands a reflexive sin:

(9) Bestemor har nettopp kjøpt hus med hage. Hun $n_{i}$ liker å være i hagen *hennes ${ }_{i}\left(V \sin _{\mathrm{i}}\right)$.

Lit.: 'Grandmother has recently bought a house with garden. She likes to be in *her.IRREFL (Vher.REFL) garden.'

Seven informants accepted this sentence, four were uncertain (based on the answer vet ikke 'don't know') and only three judged it (correctly) as ungrammatical. Even more strikingly, in non-local binding cases like (10) where Norwegian reflexives are clearly out, a number of the French informants accepted $s i^{*}$ :

(10) Christian har en søster. Søsteren ${ }^{*} \sin _{\mathrm{i}}\left(\mathrm{Vhans}_{\mathrm{i}}\right)$ er lærer.

Lit.: 'Christian has a sister. His.REFL (Vhis.IRREFL) sister is teacher.'

Five informants considered (10) as grammatical, two were uncertain, and only seven judged it (correctly) as ungrammatical.

From our data, there thus seems to be a tendency for the French No2 learner of Norwegian to overgeneralize the usage of $s i^{*}$-forms, corroborating H1 above as a false friend-effect. This pattern can be explained by the systemic differences between the languages since French does not make the reflexive-irreflexive distinction at all. When a Norwegian irreflexive hans or hennes is used wrongly instead

[5] For clarification for the reader of this paper, co-indexing has been added. 
of the reflexive $s i^{*}((7)-(9)$ above), most of our informants judge it grammatical, which means that, in this case, they base their judgment not on formal similarities between L1 and L2. We cannot rule out, either, a possible influence of English as L2 in the narrow sense. On this account, there is potential evidence for transfer, but this time from L2 to L3. As we have seen in Fabricius-Hansen et al. (2017), transfer may stem from L1 (and even Universal Grammar) or possibly L2 if the language acquired is L3 or L3+. Such questions are empirical in nature, and need further testing. For French speaking learners of Norwegian (in northern France), English may indeed be a L2 source for transfer into Norwegian L3. ${ }^{6}$ These are all instances of negative transfer.

Conversely, we expect that in cases where ${ }^{*}$-forms are used in both languages, there should be positive transfer from L1 to L2. We formulate the hypothesis in $\mathrm{H} 2$ :

H2 When $s i^{*}$ corresponds to $s^{*}$, French No2+ learners make less errors.

We find support for $\mathrm{H} 2$ in (11) below. For such cases there is in fact a vast majority of correct judgments (11/14):

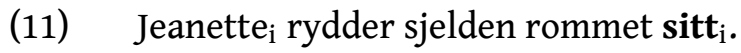

Lit.: 'Jeanette seldom cleans her.REFL room.'

However, the correct judgment of the reflexive case in (11) does not mean that all the informants have acquired the reflexivity contrast. Rather, the informants tend to interpret, more generally, the Norwegian $s i^{*}$ in accordance with the $s^{*}$-possessive in their French L1.

\section{Translation test}

Our judgment data are supported by the bilingual translation data of test 2 :

\section{Test 2: Translation into No2}

Traduisez les phrases suivantes en norvégien :"

(i) Ils ont acheté leur maison en 2010.

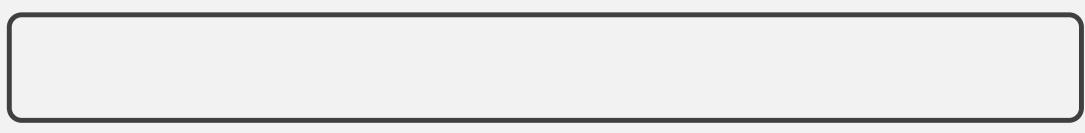

(ii) Il a oublié son sac à la maison.

[6] Transfer from L2 to L3 is labelled lateral transfer in Jarvis \& Pavlenko (2008). 
(iii) Marie a un oiseau. Son oiseau est apprivoisé.

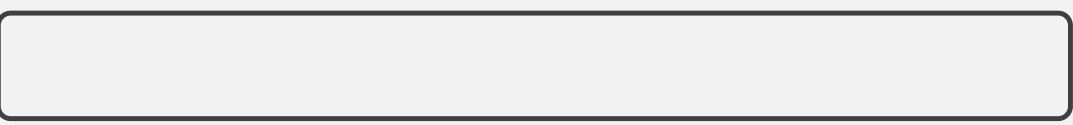

(iv) Les ouvriers se plaignent à leur patron parce qu'ils veulent améliorer leurs conditions de travail.

(v) Nous avons nos habitudes et vous avez les vôtres.

[a] Translate the following sentences into Norwegian.

In the translation test the (French) No2 learner has to decide whether to use the reflexive $\left(\mathrm{si}^{*}\right)$ or the non-reflexive forms (hans/hennes/dens/dets/deres). In addition (s)he has to choose between the prenominal or the postnominal position of the possessive, and, in the latter case, associate the position of the possessive with double definiteness (see Fabricius-Hansen et al. (2017); Julien (2003, 2005); Lødrup (2011)). It should be noted that both for the judgment and the translation test the French informants are fully aware of being tested for possessives.

Based on the fact that French lacks the reflexive-irreflexive marking, yet distinguishes between singular and plural third person possessors, we predict that French No2 learners will have problems (H1) acquiring the distinction between the possessor oriented plural interpretation of the reflexive $s^{*}$ and the irreflexive hans/hennes/deres etc. We find errors in the translation test like (12) (non-local binding requires hennes) and (13) (the correct form being sitt):

Marie $_{\mathrm{i}}$ a un oiseau. Son ${ }_{\mathrm{i}}$ oiseau est apprivoisé.

Marie har en fugl. Fuglen *sin (Vhennes) er tam.

Lit.: 'Mary has a bird. *Her.REFL (Vher.IRREFL) bird is tame.'

For (12), only seven informants chose the (correct) non-reflexive hennes, while the other half of the test group opted for the (incorrect) reflexive (fuglen *sin), sometimes with agreement errors: fuglen *sine - fuglen *si etc.

(13) $\quad \mathrm{Ils}_{\mathrm{i}}$ ont acheté leur $\mathrm{r}_{\mathrm{i}}$ maison en 2010.

De kjøpte huset *deres ( $V$ sitt) i 2010.

Lit.: 'They bought their.IRREFL ( $\sqrt{ }$ their.REFL) house in 2010.' 
Out of the fourteen informants only four chose the (correct) $s i^{*}$-form in (13), although sometimes with agreement errors: huset *sin. At a higher decision level, the possessum-oriented nature of their French mother tongue system combined with \pm reflexive-irreflexive marking makes Norwegian hard to acquire by the French speaking learners.

\section{Other cases}

As we have seen in Fabricius-Hansen et al. (2017) there are well known systemic differences between Norwegian and French at the morphological and syntactic level related to position and definiteness (see also Julien (2003, 2005); Lødrup (2011)). There is a tendency in Norwegian to postpose the possessive combined with obligatory double definiteness: bil-en hans - ${ }^{*}$ bil hans. Curiously, the position of the possessive does not seem to represent particular problems for any of the French No2 learners. Even the double definiteness feature is largely acquired, especially in the singular. For instance, the translation of leur maison in the translation test (sentence 1) has a hundred percent rate of correct definite huset followed by the (often wrong) possessive. The same goes for son sac, son oiseau and leur patron. For the plural leurs conditions de travail and nos habitudes, however, the results are quite different. Virtually none of the (fourteen) informants have acquired the definite plural. We rather get the erroneous: ${ }^{*}$ arbeidsforhold sine $-{ }^{*}$ arbeidsforhold deres instead of (the correct) arbeidsforhold-ene sine etc. ${ }^{7}$

\section{[3.2] French as L2: testing Norwegian learners' command of French possessives}

Not surprisingly, the complex nature of the reflexive-irreflexive distinction in Norwegian also plays a role when Norwegian speakers acquire French as L2. In fact, a challenge for Norwegian Fr2 learners is the problem of acquiring the possessorrelated distinction between singular $s^{*}$ and plural leur* when used reflexively. Based on the theoretical outlook of Fabricius-Hansen et al. (2017), we may thus make the following hypothesis:

H3 Norwegian Fr2 learners make errors involving $s^{*}$ and leur*. More generally, $s^{*}$ tends to be generalized in plural possessives.

We have designed three different tests in order to verify this hypothesis. The tests are mainly intended for production-comprehension data (translation and cloze tests), but they also indicate aspects of the informants' general level of linguistic knowledge (judgment test). By analyzing learner data from different sources we aim at a better understanding of the mechanisms at stake in the acquisition of French as L2.

[7] For a more general treatment of the syntax of possessives, see Fabricius-Hansen et al. (2017) and references therein: Alexiadou et al. (2007), Cardinaletti (1998). For the syntax of French possessive determiners, see Peteghem (2012) and Zribi-Hertz (2003). 


\section{Translation tests}

For Norwegian Fr2-learners we have various tests but the purpose of them is never explicitly marked. First, (bilingual) translation tests both into (test 3 below) and from Norwegian (test 4):

\section{Test 3: Translation Fr2 $\rightarrow$ No1}

Traduisez le texte suivant en norvégien : ${ }^{a}$

Nicolas Sarkozy et Carla Bruni

Il est bien rare que Nicolas Sarkozy manque un concert de sa belle Carla BruniSarkozy, qui avait dû mettre entre parenthèses sa carrière lors de son passage à l'Élysée. Il est sans doute son plus grand fan. Et lorsqu'il arrive devant la salle, on est souvent en droit de se demander si les personnes présentes ne viennent pas assister à un meeting de leur ancien président.

Depuis le début de sa tournée pleine de poésie en novembre dernier, Carla Bruni a pu compter sur le soutien inconditionnel de son époux, qui a assisté à plus d'une vingtaine de ses concerts. À Béziers, le 17 janvier dernier, il avait dit : "C'est mon dix-septième concert, mon dix-septième!"

Ce qui ne change pas, c'est l'ovation que reçoit Nicolas Sarkozy par le public, et chaque concert est donc l'occasion pour lui de constater que sa popularité reste intacte. Dès qu'il le peut, il met Carla en avant, ses talents de chanteuse, son aisance sur scène. Lorsque dans la coulisse Nicolas Sarkozy se montre un peu trop élogieux, son épouse n'hésite pas à le reprendre : "Ne parle pas trop, mon amour, ça risquerait de se retrouver dans la presse." Et lui de répondre: "Vous voyez, c'est elle la patronne de notre couple!"

Si c'est elle la patronne de leur couple, Nicolas Sarkozy reste pour beaucoup le patron de l'UMP et notre candidat le plus crédible à l'élection présidentielle de 2017. Mais si la politique fait encore partie intégrante de sa vie, Nicolas Sarkozy n'oublie pas sa famille. La preuve avec cet avion privé que loue l'ancien président pour certains concerts en province, afin de permettre à son couple de retrouver rapidement leurs enfants.

$\begin{array}{llll}\text { soutien (m) } & \text { - støtte } & \text { louer } & \text { - å leie } \\ \text { inconditionnel } & \text { - betingelsesløs } & \text { patron }(\mathrm{m}) \text {, patronne (f) }- \text { sjef } \\ \text { ovation (f) } & \text { - hyllest } & \text { crédible } & \text { - troverdig } \\ \text { aisance (f) } & \text { - letthet } & \text { preuve (f) } & \text { - bevis } \\ \text { élogieux } & \text { - rosende } & \text { en province } & \text { - i provinsen }\end{array}$

[a] 'Translate the following text into Norwegian.' For clarification again, we have put all the possessives in bold. 


\section{Test 4: Translation No1 $\rightarrow$ Fr2}

Traduisez le texte suivant en français : ${ }^{a}$

Edvard Grieg var en norsk komponist. I Norge er han best kjent for sin musikk til diktene av Aasmund Olavsson Vinje, mens det i utlandet var musikken hans til Henrik Ibsens tekster som ble lagt mest merke til. Grieg tilbrakte mye tid i utlandet, og var ofte på konsertreiser, hvor han akkompagnerte sin kone Nina Hagerup. Hun opptrådte også ofte sammen med mannen sin, og deres konserter i Europa fikk gode kritikker. Hun var en utmerket pianist, men det var først og fremst stemmen hennes og dens helt spesielle klang som fascinerte Edvard Grieg. Hagerup fortsatte også å delta på konserter etter sin manns død.

Grieg fikk sin første musikkutdannelse av moren sin. Han dro allerede som 15-åring til musikkhøyskolen i Leipzig for å studere, men fikk etter hvert et anstrengt forhold til skolen og lærerne der på grunn av deres innstilling til musikken hans. I 1867 giftet han seg med Nina Hagerup, som faktisk var kusinen hans. Deres eneste barn døde bare 13 måneder gammel, noe som var spesielt tungt for Nina, som også hadde mistet foreldrene sine. Moren hennes var teaterinstruktør og hadde hatt stor betydning for henne. I 1884 flyttet Grieg og Hagerup til Troldhaugen, hvor de bodde resten av livet.

I dag er Troldhaugen museum, og huset med møblene er godt bevart. Her kan man lære mye interessant om Edvard Grieg, hans kone og deres liv i utkanten av Bergen. På Troldhaugen blir det også arrangert konserter med band både fra Norge og fra utlandet, som kommer til Bergen med sine tolkninger av Griegs musikk.

[a] Translate the following text into French. Again, for clarification, we have put all the possessives in bold.

The French text (test 3) has a number of possessives to be dealt with, for instance sa belle Carla Bruni 'his beautiful CB' - sa carrière 'her career' - son passage 'his accession to...' - son plus grand fan 'her biggest fan' - leur ancien president 'their former president' - son époux 'her husband' - ses concerts 'her concerts' - mon dix-septième concert 'my 17th concert' etc. These include both reflexive (locally bound) and non-reflexive (non-locally bound) uses in French, which must be made explicit in Norwegian; third person singular and plural possessives, first and second person deictic possessives, position of the possessive, and so on.

The Norwegian text (test 4) is the other way around. Explicit reflexive and non-reflexive marking in the third person singular and plural of Norwegian must be rendered in the less morphologically specified French system. In other words, the predominantly possessor-oriented system of Norwegian must find its correspondences in the possessum-oriented system of French. The Norwegian text has forms like sin musikk 'his.REFL music' - musikken hans 'his.IRREFL music' - sin kone (his.REFL wife) - mannen sin 'her.REFL husband' - deres konserter 'their.IRREFL concerts' - stemmen hennes 'her.IRREFL voice' - dens helt spesielle klang 'its.IRREFL exceptional 
sound' - sin manns død 'the death of her.REFL husband' etc.

The translation tests had participants both from the University of Oslo and the University of Caen, thus marking the distinction between students in an immersion context (Caen) and Norwegian students at home (Oslo). The Caen students were Norwegian students going to France (Caen) for one year studying French as L2 based on the Norwegian university system. The Norwegian students of French L2 at the University of Oslo follow the same program, but this time in a local Oslo University setting.

For the French to Norwegian (Fr2 $\rightarrow$ No1) translation, we had 36 L2 learners of French at the University of Oslo during the autumn of 2015 and 14 L2 learners of French in an immersion context at the University of Caen. For the Norwegian to French translation, we had $21 \mathrm{~L} 2$ learners of French at the University of Oslo during the autumn of 2015 and 14 L2 learners of French in an immersion context at the University of Caen. Both groups had studied French grammar at the University level for about two months (requiring that they have two years of training in French from upper secondary school) and had been exposed to explicit teaching and training in determiner syntax and semantics, including possessives. The testing was done in the classroom and took approximately half an hour.

$\mathrm{H} 3$ is easily corroborated by our data. In the translation test 4 (No1 $\rightarrow \mathrm{Fr} 2$ ), we find the following examples:

(14) $\quad$ Hun $_{\mathrm{i}}$ opptrådte ofte sammen med mannen $\sin _{\mathrm{i}}$, og ([hun og mannen $\left.\left.\sin \right]_{\mathrm{j}}=\right)$ deres $s_{j}$ konserter i Europa fikk gode kritikker.

Lit.: 'She often acted with her.REFL husband and their.IRREFL concerts in Europe received good reviews.'

(15) På Troldhaugen blir det også arrangert konserter med band $d_{i}$ både fra Norge og fra utlandet, som kommer til Bergen med sine $\mathbf{e}_{\mathrm{i}}$ tolkninger av Griegs musikk.

Lit.: 'At Troldhaugen concerts are also staged with bands both from Norway and abroad that come to Bergen with their.REFL interpretations of Grieg's music.'

Both in (14) and (15) there are semantically plural possessors: she and her husband for the non-reflexive deres (14) and bands from Norway and abroad for the reflexive sine (15). Our immersion-group from Caen, having fourteen participants, had no problems at all rendering deres konserter in their French translations. Of the 14 informants, only one missed out by saying *ses concerts. The rest of the group used the correct stem form leur*, even with the correct possessum-agreement in all but one case: leurs concerts. This shows that the possessor-related plural possessive leur* has indeed been integrated in the students' L2 grammar in its non-reflexive (non-locally bound) use. 
Turning now to (15), where the reflexive possessive sine is related to the lexical plural possessor bands from...., the results in the same Caen group are quite different. In this case, only three out of 14 participants chose leur*. Six of them opted for a variant of the incorrect stem form $s^{*}$, while the rest of the group (five participants) either chose a non-possessive variant or did not answer the question. Since the same group had shown earlier in the test that they had in fact learned the correct plural possessor-related form leur, the high percentage of $s^{*}$-forms for Norwegian sine indicates a strong transfer effect.

In the same vein we occasionally find transfer errors for Fr2 learners' translations from French source texts into Norwegian L1 (test 3) when the Norwegian reflexive si-form is clearly ungrammatical (the example is taken from the Caen immersion group):

(16) Mais si la politique fait encore partie intégrante de $\mathbf{s a}_{\mathrm{i}}$ vie, Nicolas Sarkozy n'oublie pas sa $\mathbf{a}_{\mathrm{i}}$ famille.

Men hvis politikken tar enda del av *sitt ( hans) liv, glemmer ikke Nicolas Sarkozy sin familie (= sa famille).

Lit.: 'But if politics is still an integrated part of *his.REFL (Vhis.IRREFL) life, Nicolas Sarkozy does not forget his.REFL family.'

The correct forms should be non-reflexive for the first possessive (hans liv), and reflexive for the second ( $\sin$ familie). This seems to be an example of L2 to L1-transfer (or reverse transfer in the sense of Jarvis \& Pavlenko (2008)).

Even in cases where Norwegian uses postnominal possessives, the $s i^{*}-s^{*}$ correspondence is early established, with very few errors. In the translation test No1 $\rightarrow \mathrm{Fr} 2$ of (17) containing the postnominal sin, all the informants in the Caen group had the translation right, 19/21 in the Oslo group:

(17) Hun $n_{\mathrm{i}}$ opptrådte også ofte med mannen $\sqrt{ } \sin _{\mathrm{i}} \ldots$

Lit.: 'She acted also often with her.REFL husband.'

Hence, for (17), all the Caen informants used the correct form son followed by mari or homme. Son mari in all but one out of 19 in the Oslo group, the error being feminine $s a$ for son in the single case. We conclude that $s^{*}$-transfer seems to be generalized both for correct (17) cases (positive transfer) and for incorrect ones (negative transfer) (15). H3 above could then be subsumed under the more general $\mathrm{H} 4$ :

H4 Norwegian learners of French generalize the transfer of $s i^{*}$ to $s^{*}$ in their L2 grammar. 


\section{Cloze test}

In order to test further $\mathrm{H} 2$ and $\mathrm{H} 3$, we combined the translation tests with a monolingual cloze test (test 5) aimed at testing the production of determiners of all kinds given at the end of the first semester of French studies at the University of Oslo during the autumn of 2014 ( 55 informants). The cloze test took the following form:

\section{Test 5: Cloze test for Norwegian Fr2-learners}

\section{Déterminants}

Insérez les déterminants nécessaires dans le texte ci-dessous. Expliquez l'emploi ou le non emploi de déterminant devant les noms homme politique, mains, écrivain, premier étage, fenêtre (la deuxième occurrence) et lune. ${ }^{a}$

Jean Acault, homme politique, vient de publier livre sur gouvernement français et mains pour la première fois, écrivain, et a aidé grande maison à voiture. À

pour fenêtre, Jean regarde étoiles à décisions actuelles. Quand il l'a eu dans yeux rayonnaient de joie. femme est mari à rédiger livre. Ils se sont installés dans campagne, mais ils n'ont pas encore premier étage, il y a grande fenêtre. Par garage lune tous les soirs, et souvent il voit nombreuses

[a] Insert determiners if necessary in the following text. Explain the use or the non-use of a determiner in front of the nouns homme politique, mains, écrivain, premier étage, fenetre (second occurrence) and lune.

There are well known differences between French and Norwegian in such cases. The tendency is to mark the possessive relation more explicitly in French than in Norwegian. For instance, one could easily find cases like (18) from test 5 which would exhibit definite determiners in corresponding No1-cases like (19), but where it's more natural to choose the possessive determiner in French:

(18) Quand $\mathrm{i}_{\mathrm{i}}$ l'a eu dans ses $\mathrm{i}_{\mathrm{i}} /$ ??les mains pour la première fois, ses $\mathrm{i}_{\mathrm{i}} /$ ??les yeux rayonnaient de joie. $S a_{\mathrm{i}} /$ ??la femme est Ø écrivain, et a aidé $\boldsymbol{s o n}_{\mathrm{i}} /$ ??le mari à rédiger $\boldsymbol{s o n}_{\mathrm{i}} /$ le livre.

Lit.: 'When he got it in his/(the) hands for the first time, his/(the) eyes shone of joy. His/(the) wife is an author, and helped her/(the) husband to write his/(the) book.'

(19) Da han fikk den i hendene for første gang, skinte øynene hans av glede. Kona hans er forfatter og hjalp mannen med å redigere boka.

Unlike French, the Norwegian system is much more flexible for the marking of the possessive relation, relying more heavily on contextual input (see Woldsnes (2013)). As long as the possessive relation is clear from context, Norwegian tolerates def- 
inite determiners to a large extent where this choice would seem too vague in French. The informants must also distinguish between (non-marked) reflexive and non-reflexive determiners in French and of course make the distinction between third person singular and plural possessors. Recall that Norwegian does not make the distinction between third person singular and plural possessors for reflexive uses: .... mais ils $\mathrm{s}_{\mathrm{i}}$ 'ont pas encore de garage pour Vleur ${ }_{\mathrm{i}}$ voiture. Lit.: '...but they still don't have a garage for their car.'

The test group chose the correct form leur in about half of the cases (26 answers containing leur). Because of the tendency in Norwegian to use less specific possessive marking, 18 participants used the (less natural) definite article (la voiture). Eight of the informants however chose the incorrect sa voiture - again a clear transfer effect - while three of them hesitated between the definite la and plural leur (both options were indicated in the candidates' answer). We see then that the cloze test gives additional support to hypotheses $\mathrm{H} 3$ and $\mathrm{H} 4$.

\section{Judgment test}

The third kind of test we used for our Fr2-informants was a monolingual grammaticality judgment test (test 6) intended for the two groups of Norwegian students of French in France and Norway. The tests were given in November 2016 during the students' first semester of French studies at the University level, either at the University of Oslo or at the University of Caen in an immersion context. In both cases, the tests were given in the classroom and took between twenty and thirty minutes. We had $40 \mathrm{~L} 2$ learners of French at the University of Oslo with Norwegian as L1 (in addition to seven informants with Norwegian not as L1), and $15 \mathrm{~L} 2$ learners of French in an immersion context at the University of Caen. The students in these groups differed from those doing the translation or cloze tests presented above, although both groups had been exposed to the same teaching and training of determiner syntax and semantics beforehand. Below are listed some relevant test cases (see appendix for the full test):

\section{Test 6: Grammaticality judgment test for Norwegian Fr2-learners}

Les déterminants

Jugez la grammaticalité des déterminants soulignés dans les exemples suivants. ${ }^{a}$

(i) Claire et Paul se sont installés à la campagne avec ses trois enfants.

$$
\text { la }=\text { riktig/feil/vet ikke ses = riktig/feil/vet ikke }
$$


(ii) Les Dupont font ses courses une fois par semaine.

Les $=$ riktig/feil/vet ikke ses = riktig/feil/vet ikke

(iii) Il avait oublié son sac à la maison.

$$
\text { son }=\text { riktig/feil/vet ikke la }=\text { riktig/feil/vet ikke }
$$

(iv) Les trois sœurs vont toutes à la même école. Son école se situe près de la maison.

$$
\text { la }=\text { riktig/feil/vet ikke son }=\text { riktig/feil/vet ikke }
$$

[a] Judge the grammaticality of the underlined determiners in the following examples: acceptable/non-acceptable/don't know.

The test contains 50 sentences with different kinds of determiners: definite, demonstrative, possessive, indefinite, partitive or quantitative determiners, gender issues, correct uses, errors and so on. For our purposes, possessives occur in 24 of the 50 test sentences. ${ }^{8}$ In examples like (2) above (our (21) below), we have blatant errors of possessor agreement (ses is ungrammatical, leurs is correct):

(21) Les Dupont font $^{*}$ ses $_{\mathrm{i}}\left(\right.$ Vleurs $\left._{\mathrm{i}}\right)$ courses une fois par semaine.

Lit.: 'The Dupont family do their shopping once a week.'

In other cases, the correct forms occur:

(22) $\mathrm{Il}_{\mathrm{i}}$ avait oublié son $_{\mathrm{i}} \mathrm{sac}$ à la maison.

Lit.: 'He had forgotten his bag at home.'

There are both reflexive (like (21)-(22)) and non-reflexive uses (23). In (23), the $\mathrm{R}$ (eflexivity)-neutral son is (non-locally) bound from outside the clause (obeying to principle B of Binding Theory, (Chomsky 1981)), but the binder is plural, hence the ungrammaticality of son. The correct form would be leur:

(23) Les trois sœurs $\mathrm{i}_{\mathrm{i}}$ vont toutes à la même école. ${ }^{*} \mathrm{Son}_{\mathrm{i}}\left(\mathrm{Vleur}_{\mathrm{i}}\right)$ école se situe près de la maison.

Lit.: 'The three sisters all attend to the same school. Their school is situated near their home.'

[8] With the numbering from the test, we have the sentences (2), (5), (7), (9), (10), (13), (15), (17), (19), (22), (25), (26), (30), (32), (34), (37), (38), (40), (42), (43), (45), (47), (49) and (50). See appendix for the full test. 
The informants judge the cases in the test on the basis of three options: correct, incorrect or uncertain.

Many results from the judgment test strengthen $\mathrm{H} 3$ and H4. Example (2) from the test above takes the form of (24):

[Claire et Paul] $]_{\mathrm{i}}$ se sont installés à la campagne avec *ses $_{\mathrm{i}}\left(\right.$ Vleurs $\left._{\mathrm{i}}\right)$ trois enfants.

Lit.: 'Claire and Paul moved into the countryside with their three children.'

The $s$-possessive in (24), demanding a singular possessor, is of course incorrect and should be replaced by leurs (trois enfants). In the Caen immersion group this time (autumn 2016), we had 15 participants. 12 out of them judged the example with the incorrect ses as grammatical, one was uncertain and only two had it right. In (24) the possessive is locally bound, but even in cases where we could not have a reflexive in Norwegian, the same kind of $s^{*}$-transfer seems to occur.

In (23), the reflexive possessive is strongly ungrammatical in Norwegian (*sin skole), the correct form being deres (skole). Still 12 out of 40 informants in the Oslo group and 8/15 in the Caen group judged the incorrect son grammatical. The Norwegian Fr2-groups thus still seem to be (unconsciously) influenced by the (partly) false friends $s i^{*}$ and $s^{*}$ (see Fabricius-Hansen et al. (2017, section 4)) and even overgeneralize the usage of $s^{*}$ in corresponding cases where the $s^{*}$-form is excluded in Norwegian.

The $s i^{*}-s^{*}$-transfer from Norwegian to French also means that in cases where the $s^{*}$-possessive is (or should be) used in both languages the success rate of correct correspondences tends to rise. This prediction is borne out. In the judgment test for (25) (test 6), 39 out of 40 informants in the Oslo group judged the possessive son fully grammatical, 15/15 in the Caen (immersion) group:

(25) $\mathrm{Il}_{\mathrm{i}}$ avait oublié $\sqrt{ } \mathbf{s o n}_{\mathrm{i}}$ sac à la maison.

Lit.: 'He had forgotten his bag at home.'

Thus, we find support for $\mathrm{H} 3$ and $\mathrm{H} 4$ from the judgment test, both from negative (23)-(24) and positive transfer (25), but positive transfer effects don't indicate by themselves that the possessive system of French has been (fully) internalized.

Possessum- vs. possessor-related possessives

Since Norwegian possessives, contrary to French, are generally possessor oriented, we predict errors relating to the directions of the corresponding referent like the following:

(26) *Son maison (for sa maison à lui)/*Son voiture (for sa voiture à lui) 'His house/his car' 
We might therefore formulate a more general hypothesis like:

H5 Norwegian Fr2 learners relate the possessive to the possessor rather than the possessum.

Admittedly, it is much harder to test this hypothesis than H1-H4 above. The problem is actually how to separate common problems of acquiring the gender of the head noun (the possessum) - and hence more directly determiner-noun agreement - from the (anaphoric) orientation of the possessive towards a masculine or feminine possessor. We do however find possible evidence for $\mathrm{H} 5$.

In the translation test Norwegian-French (test 4), we have the sentence in (27):

I 1867 giftet han ${ }_{\mathrm{i}}$ seg med Nina Hagerup, som faktisk var kusinen hans . $_{\mathrm{i}}$

Lit.: 'In 1867 he married Nina Hagerup who actually was his.IRREFL cousin.'

The correct translation of kusinen hans is sa cousine, which is neutral with respect to reflexivity (binding conditions) and shows gender and number agreement between possessive and possessum (the following noun). Two participants - one from the Caen group and the other from the Oslo group chose to translate kusinen hans by son cousine instead of the correct sa cousine. These could well be instances of wrong possessor orientation, because in other cases the same informants show that they have indeed acquired the correct feminine forms of the possessive (sa femme - sa mère etc.). Another possible instance comes from the translation test from French to Norwegian (test 3) with the sentence in (28):

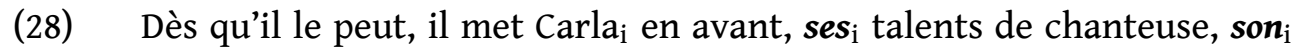
aisance sur scène.

Lit.: 'As soon as he can, he puts forward Carla, her talent as a singer, her ease on stage.'

Most of the informants, either in the Caen group or the Oslo group, opt for the correct non-reflexive possessives in their translations: hennes sangtalent og hennes dyktighet på scenen. The possessum related possessive in French entails different forms of the possessives ses talents (masculine plural) and son aisance (son in front of a singular feminine noun starting with a vowel). Two of the participants in the Oslo group rendered the two possessives in (28) by (29): ${ }^{9}$

$$
\begin{aligned}
& \text {... Vhennes talent og *hans N... } \\
& \text { '...her.IRREFL talent and his.IRREFL N...' }
\end{aligned}
$$

This might indicate that these informants erroneously take the ses-son-distinction in the coordinated structure of French to mark a gender opposition of possessors.

[9] In both cases the translation of aisance is wrong, but this is irrelevant for our discussion here, hence the $\mathrm{N}$ feature. 
A third possible instance of possessor oriented transfer from Norwegian to French (test 4) could be the translation of musikken hans in (30):

...Mens det i utlandet var musikken hans til Henrik Ibsens tekster som ble lagt merke til.

Lit.: '...while abroad his.IRREFL music to Henrik Ibsen's texts were noticed.'

4/14 in the Caen group and 5/21 in the Oslo group translate the non-reflexive Norwegian masculine possessive by son: *son musique (instead of the correct sa musique). This might indicate that at least some of these informants relate the possessive * son to a masculine possessor. However, for this latter type of examples it cannot be ruled out that it is just an error of assigning the correct gender to the head noun, taking it to be masculine (as in Norwegian) instead of feminine. All in all, for hypotheses of possessor related possessives in $\mathrm{Fr} 2$ - as postulated in $\mathrm{H} 5$ we must design more solid tests.

Other cases

The tests we have already constructed could be useful also for further acquisition issues between No1 and Fr2. As noted above, there is a strong tendency of marking the possessive relation more frequently in French than in Norwegian (see also Fabricius-Hansen et al. (2017, section 3.2)). An example from the cloze test gives us a point at hand:

(31) Quand il l'a eu dans...mains pour la première fois, ...yeux rayonnaient de joie.

Lit.: 'When he got it in...hands for the first time, ...eyes shone of joy.'

In this case, it's more natural in French to use possessives than definites:

(32) Quand $\mathrm{i}_{\mathrm{i}}$ l'a eu dans ses $\mathrm{i}_{\mathrm{i}}$ mains pour la première fois, ses $_{\mathrm{i}}$ yeux rayonnaient de joie.

Lit.: 'When he got it in his hands for the first time, his eyes shone of joy.'

The high percentage of definites in the results from the Oslo group shows however that the informants seem to be influenced by their Norwegian L1-system. 35/55 opt for the definite (les) in front of mains:

(33) Quand il l'a eu dans les mains pour la première fois...

Lit.: 'When he got it in the hands for the first time...'

In other cases too we see a tendency of less explicit possessive marking in Norwegian than French. This became very clear from (20) above, repeated in (34), for which 18 of 55 informants in the cloze test chose a definite determiner (35) instead of the more natural possessive in (36): 
...mais ils n'ont pas encore...garage pour...voiture. ...mais ils n'ont pas encore de garage pour la voiture.

(36) ...mais ils $s_{i}$ n'ont pas encore de garage pour Vleur $_{i}$ voiture.

Lit.: '...but they still don't have a garage for the/their car.'

In a similar vein, Norwegian may have the definite determiner in the source text for translation where French clearly would opt for a possessive:

\section{1884 flyttet Grieg og Hagerup til Troldhaugen hvor de bodde resten av livet.}

Lit.: 'In 1884 Grieg and Hagerup moved to Troldhaugen where they lived for the rest of the life.'

In the Caen group, 4/14 informants chose to keep the definite in their French translation (pour le reste de la vie) instead of the much more natural possessive: pour le reste de leur vie. Only five out of 14 used the leur-form correctly while two made the expected transfer error (pour le reste de *sa vie) and three informants gave no answer at all.

Finally, all the French L2+ tests above indicate that the position of the possessive - Norwegian admitting both prenominal and postnominal possessives does not seem to represent a problem at all. In fact, we don't have a single occurrence of Fr2 postnominal possessive in our corpus. Thus, the prediction that the various (prenominal or postnominal) positions of the possessives in the learner's mother tongue (Norwegian as L1) should create problems for her acquisition of the French system is not borne out. This may also well be due to the intervention effect of learning English as L2 before French as L3 in the strict sense ((positive) transfer from L2 to L3). The learner has already acquired a system (English as L2) where possessives are necessarily put in front of the head noun. Regardless of the learner's proficiency in French as L3 (morphological errors, reflexivity parameter, definite or possessive marking etc.), she always puts the possessive determiner in front of the head noun. Hence, even though her L1 grammar allows both preposed and postposed possessives, this option is excluded for her L2 grammar of English and L3 grammar of French.

\section{[4] CONCLUDING REMARKS}

We have observed that Norwegian learners of French L2 tend to mix up the inherent possessor-related dependencies of Norwegian with the possessum-related orientation of French (see Fabricius-Hansen et al. (2017, section 4)). Data from different sources (translation, cloze test and judgment tests) show evidence for possessor-related transfer from Norwegian L1 to French L2. Thus, there is a generalized usage of $s o n / s a / s e s$ by Norwegian learners of French $\mathrm{L} 2$ both for the reflexive 
third person singular and third person plural exactly where Norwegian has $s i^{*}$ in both cases. The morpho-phonological $s^{*}-s i^{*}$ similarity may even lead to Norwegian reflexives in translations from French under binding conditions where Norwegian reflexives are clearly ruled out ('shallow' priming according to Pitz et al. (2017); see also Fabricius-Hansen et al. (2017, section 4) and Behrens (2017)).

For French No2 learners, the complexity of the Norwegian system leads to problems first of all for the reflexive-irreflexive distinction in addition to overgeneralization of $s i$. The reflexivity contrast is clearly extremely hard to acquire for French speaking learners. This prediction should be tested further both for the $s i{ }^{*}$ versus hans/hennes/dens/dets-distinction in the third person singular and the $s i^{*}$-versus deres-distinction in the third person plural. In further works we will follow up these learner language studies and augment the experiments for the assessment of general interlanguage development.

\section{A P P E N D I X}

\section{Test 1: No2 grammaticality judgment test}

Le possessif en norvégien

Test de jugement grammatical ${ }^{a}$

Déterminez si les possessifs soulignés dans les phrases suivantes sont acceptables ou non. Akseptabel $=$ acceptable/ikke akseptabel $=$ non acceptable/vet $i k k e=$ je ne sais pas.

(i) Kristoffer har tre brødre, men han har ikke sett den yngste av brødrene hans det siste året.

hans $=$ akseptabel/ikke akseptabel/vet ikke

(ii) Jeanette rydder sjelden rommet sitt.

sitt $=$ akseptabel/ikke akseptabel/vet ikke

(iii) Christian har en søster. Søsteren sin er lærer.

$\sin =$ akseptabel/ikke akseptabel/vet ikke

(iv) Foreldrene solgte huset sitt da de flyttet til Frankrike.

sitt = akseptabel/ikke akseptabel/vet ikke 
(v) Jeg skal besøke Caroline og familien sin. $\sin =$ akseptabel/ikke akseptabel/vet ikke

(vi) Marie fant ikke boka si.

$s i=$ akseptabel/ikke akseptabel/vet ikke

(vii) Nikolai har vondt i armen hans, men vil ikke gå til legen.

hans $=$ akseptabel/ikke akseptabel/vet ikke

(viii) Huset sitt ligger utenfor byen, så hun har lang vei til skolen.

sitt = akseptabel/ikke akseptabel/vet ikke

(ix) Anne er sint på moren $\underline{\sin }$ fordi hun ikke liker den nye mannen hennes.

sin $=$ akseptabel/ikke akseptabel/vet ikke

hennes $=$ akseptabel/ikke akseptabel/vet ikke

(x) Det nye huset vårt ligger ganske nærme leiligheten $\underline{\text { din. }}$.

vårt $=$ akseptabel/ikke akseptabel/vet ikke din = akseptabel/ikke akseptabel/vet ikke

(xi) Bestemor har nettopp kjøpt hus med hage. Hun liker å være i hagen hennes. hennes $=$ akseptabel/ikke akseptabel/vet ikke

(xii) Barna våre spiser aldri opp maten sin.

våre $=$ akseptabel/ikke akseptabel/vet ikke $\sin =$ akseptabel/ikke akseptabel/vet ikke

[a] 'Grammaticality judgment test. Decide if the underlined possessives in the following sentences are acceptable or not: acceptable/non-acceptable/don't know.' 


\section{Test 6: Fr2 grammaticality judgment test}

\section{Les déterminants}

Jugez la grammaticalité des déterminants soulignés dans les exemples suivants.

(i) Le petit garçon ne mange pas de la glace pendant l'hiver.

de la = riktig/feil/vet ikke

$l^{\prime}=$ riktig/feil/vet ikke

(ii) Claire et Paul se sont installés à la campagne avec ses trois enfants.

la = riktig/feil/vet ikke

ses $=$ riktig/feil/vet ikke

(iii) Ils viennent d'acheter une nouvelle voiture.

une $=$ riktig/feil/vet ikke

(iv) L'étudiant a emprunté des argents à un ami.

des $=$ riktig/feil/vet ikke

un $=$ riktig/feil/vet ikke

(v) Les Dupont font ses courses une fois par semaine.

Les $=$ riktig/feil/vet ikke

ses $=$ riktig/feil/vet ikke

(vi) Marie et son collègue ont des problèmes de communication.

des = riktig/feil/vet ikke

(vii) Il avait oublié son sac à la maison.

son = riktig/feil/vet ikke

la = riktig/feil/vet ikke 
(viii) Il ne boit pas du café le soir.

$$
\begin{aligned}
& d u=\text { riktig/feil/vet ikke } \\
& l e=\text { riktig/feil/vet ikke }
\end{aligned}
$$

(ix) Cécile a besoin d'une étagère pour pouvoir ranger ses livres.

une $=$ riktig/feil/vet ikke

ses $=$ riktig/feil/vet ikke

(x) Toutes les familles sont bien rentrées à ses maisons.

les $=$ riktig $/$ feil/vet ikke

ses $=$ riktig/feil/vet ikke

(xi) Cette compagnie a des centaines de salariés.

cette $=$ riktig/feil/vet ikke

des $=$ riktig/feil/vet ikke

(xii) Le professeur a monté ce escalier rapidement.

$L e=$ riktig/feil/vet ikke

$c e=$ riktig/feil/vet ikke

(xiii) Tous les élèves avaient fait ses devoirs.

les $=$ riktig $/$ feil/vet ikke

ses $=$ riktig/feil/vet ikke

(xiv) Cette ville est pleine des musées intéressants.

des = riktig/feil/vet ikke

(xv) Il est très content de ses nouvelles chaussures.

ses $=\mathrm{riktig} / \mathrm{feil} / \mathrm{vet} \mathrm{ikke}$ 
(xvi) Lisa cherche une maison spacieuse aux alentours d'Oslo.

$$
\text { une }=\text { riktig/feil/vet ikke }
$$

(xvii) Les enfants sont arrivés, tous avec ses parents.

Les $=$ riktig/feil/vet ikke

ses $=$ riktig/feil/vet ikke

(xviii) Le chalet est entouré du forêt.

$d u=$ riktig/feil/vet ikke

(xix) Elle range sa chambre tous les soirs.

$s a=$ riktig/feil/vet ikke

les $=$ riktig/feil/vet ikke

(xx) Christine commande toujours le plat le plus cher.

$l e=$ riktig/feil/vet ikke

(xxi) Claude avait planté beaucoup des fleurs dans le jardin.

des = riktig/feil/vet ikke

le $=$ riktig/feil/vet ikke

(xxii) Claire et Paul garent sa nouvelle voiture dans le garage.

$s a=$ riktig/feil/vet ikke

$l e=$ riktig/feil/vet ikke

(xxiii) Elle a fait un gâteau sans du sucre.

un = riktig/feil/vet ikke

$d u=$ riktig/feil/vet ikke 
(xxiv) Julia prend le même bus tous les matins.

$$
\text { les }=\text { riktig/feil/vet ikke }
$$

(xxv) Paul aime s'occuper de son jardin.

son $=$ riktig/feil/vet ikke

(xxvi) Ils ont deux fils. Ses fils ont tous les deux commencé à étudier à l'Université de Bourgogne.

Ses $=$ riktig/feil/vet ikke

les $=$ riktig/feil/vet ikke

(xxvii) Claire a rencontré un homme dans le supermarché. Elle trouve ce homme étrange.

$l e=$ riktig/feil/vet ikke

$c e=$ riktig/feil/vet ikke

(xxviii) Elle a commencé à travailler à Strasbourg l'année dernière.

$$
l^{\prime}=\text { riktig/feil/vet ikke }
$$

(xxix) La mère de Julia connaît toujours la bonne réponse.

la $=$ riktig/feil/vet ikke

(xxx) Jeanne et Gabrielle ont acheté des livres sur la Norvège. Elles trouvent ses nouveaux livres intéressants.

des $=$ riktig/feil/vet ikke

ses $=$ riktig/feil/vet ikke

(xxxi) Les étudiants écoutent le professeur avec d'enthousiasme.

le $=$ riktig/feil/vet ikke

$d^{\prime}=$ riktig/feil/vet ikke 
(xxxii) Il fait ses devoirs le soir, mais il les trouve toujours difficiles.

ses $=$ riktig/feil/vet ikke

$l e=$ riktig/feil/vet ikke

(xxxiii) Le Château de Versailles est un des châteaux les plus connus du monde.

les $=$ riktig/feil/vet ikke

$d u=$ riktig/feil/vet ikke

(xxxiv) Les trois sœurs vont toutes à la même école. Son école se situe près de la maison.

la $=$ riktig/feil/vet ikke

Son $=$ riktig/feil/vet ikke

(xxxv) Les trois collègues ont pris un grand bateau pour aller au nord de la Norvège. Cet bateau est impressionnant.

un $=$ riktig/feil/vet ikke

Cet $=$ riktig $/$ feil/vet ikke

(xxxvi) Jacques cherche un bon restaurant pour le repas du midi.

le $=$ riktig/feil/vet ikke

$d u=$ riktig/feil/vet ikke

(xxxvii) Madame Dupont trouve sa belle-fille adorable.

$s a=$ riktig/feil/vet ikke

(xxxviii) Les Lefébure ont des journaux partout dans le salon, mais ses journaux sont tous vieux.

des $=$ riktig/feil/vet ikke

ses $=$ riktig/feil/vet ikke 
(xxxix) Christine aime du chocolat.

$$
d u=\text { riktig/feil/vet ikke }
$$

(xl) Il s'occupe toujours très bien de ses petits frères.

$$
s e s=\text { riktig/feil/vet ikke }
$$

(xli) Quelqu'un a volé le sac à main de Marie. Le sac à main était gris.

$$
l e=\text { riktig/feil/vet ikke }
$$

(xlii) Mes parents ont des voisins bizarres. Ses voisins sont aussi impolis.

$$
\begin{aligned}
& \text { des }=\text { riktig/feil/vet ikke } \\
& \text { Ses }=\text { riktig/feil/vet ikke }
\end{aligned}
$$

(xliii) David a acheté sa nouvelle voiture à Berlin.

$$
s a=\text { riktig/feil/vet ikke }
$$

(xliv) Mes parents n'ont pas pu trouver suffisamment des verres pour ce soir.

$$
\begin{aligned}
& \text { Mes = riktig/feil/vet ikke } \\
& \text { des = riktig/feil/vet ikke }
\end{aligned}
$$

(xlv) Les élèves sont contents de son nouveau professeur d'anglais.

Les $=$ riktig/feil/vet ikke

son $=$ riktig/feil/vet ikke

(xlvi) Isabelle lit un livre avant de se coucher.

$$
\text { un }=\text { riktig/feil/vet ikke }
$$


(xlvii) Paul a menti à son patron. son $=$ riktig/feil/vet ikke

(xlviii) J'ai accepté cet emploi sans hésiter.

cet $=$ riktig/feil/vet ikke

(xlix) Les deux frères font le ménage pour ses grands-parents le lundi.

ses $=$ riktig/feil/vet ikke

$l e=$ riktig/feil/vet ikke

(l) Cette femme a influencé la mode avec son style.

la $=$ riktig/feil/vet ikke

son $=$ riktig/feil/vet ikke

Merci!

\section{REFERENCES}

Alexiadou, Artemis, Liliane Haegeman \& Melita Stavrou. 2007. Noun phrase in the generative perspective. Berlin: De Gruyter.

Behrens, Bergljot. 2017. Processing possessives in translation between unequal systems: An exploratory study. Oslo Studies in Language 9(2). 105-136.

Cardinaletti, Anna. 1998. On the deficient/strong opposition in possessive systems. In Artemis Alexiadou \& Chris Wilder (eds.), Possessives, predicates, and movement in the determiner phrase, 17-53. Amsterdam: Benjamins.

Chomsky, Noam. 1981. Lectures on government and binding. Dordrecht: Foris.

Fabricius-Hansen, Cathrine, Hans Petter Helland \& Anneliese Pitz. 2017. An L2 perspective on possessives: Contrasts and their possible consequences. Oslo Studies in Language 9(2). 3-39.

Jarvis, Scott \& Aneta Pavlenko. 2008. Crosslinguistic influence in language and cognition. London: Routledge. 
Julien, Marit. 2003. Double definiteness in Scandinavian. Nordlyd 31(1). 230-244.

Julien, Marit. 2005. Nominal phrases from a Scandinavian perspective. Amsterdam: Benjamins.

Lødrup, Helge. 2011. Norwegian possessive pronouns: Phrases, words or suffixes. In Miriam Butt \& Tracy Holloway King (eds.), Proceedings of the LFG11 conference, 339-359. Stanford: CSLI Publications.

Peteghem, Marleen van. 2012. Possessives and grammaticalization in Romance. Folia Linguistica 46(2). 605-634.

Pitz, Anneliese, Oliver Bott, Torgrim Solstad, Robin Hörnig, Bergljot Behrens \& Cathrine Fabricius-Hansen. 2017. An empirical L2 perspective on possessives: German/Norwegian. Oslo Studies in Language 9(2). 41-74.

Woldsnes, Anne-Kathrine. 2013. La possession inaliénable - une analyse contrastive. Oslo: University of Oslo.

Zribi-Hertz, Anne. 2003. On the assymetrical but regular properties of French possessive DPs. In Martine Coene \& Yves D'Hulst (eds.), From NP to DP: The expression of possession in noun phrases, 141-163. Amsterdam: Benjamins.

AUTHOR CONTACT INFORMATION

Hans Petter Helland

University of Oslo

h.p.helland@ilos.uio.no 